\title{
Public research
}

\section{Public research funding and research policy: a long-term analysis for the Swiss case}

\section{Benedetto Lepori}

In this paper, an analysis is proposed of the evolution of public research in Switzerland from World War II to the year 2000. Thanks to the combination of different data sources, we produce a set of indicators for the overall volume of funding, the share of projects funds, and the share of the higher-education sector in the public research sector. Results are then linked to the development of the Swiss research and highereducation policy in the same period, leading to the identification of a major turning point at the end of the 1960s, when today's domination of higher education in the public research sector started.
Benedetto Lepori is in the Research Service, Università della Svizzera Italiana, via Lambertenghi 10a, CH-6904 Lugano, Switzerland; Tel: +41 5866646 14/7; Fax: +41 5866646 19; Email: blepori@unisi.ch.
7 HE EVOLUTION OF public funding is a central concern in research policy studies for two main reasons. First, in most countries, public subsidies are the main tool for the implementation of research policy and, thus, we expect that the level of funds available and the criteria adopted for their repartition should be directly linked to policy objectives and to the power relationships among the actors involved. This relationship would also mean that changes over time in funding should be correlated with the overall evolution of research policy models (Braun, 2003; Guston, 2000). Secondly, in the 20th century, public funding became the prevalent source of resources for public research organizations; thus, we expect that changes in the composition of public funding will impact on the organization of research.

The literature on the subject has identified some general trends during the last three decades. These include: a leveling-off of funding since the 1970s, contrasting with the rapid increase in the period following World War II (Ziman, 1994); a shift from block funding to contractual relationships, where funding is linked to performance indicators (Geuna, 2001; Geuna and Martin, 2003); and the increasing share of project funding over general funding plus a shift from academic programs to programs oriented towards policy needs and economic innovation (OECD, 2003a).

However, even if these trends are accepted at a qualitative level, for European countries we lack a detailed reconstruction of the evolution of public funding covering a sufficiently long period to examine the relationship between the changes in funding and those in research policy. Thus, even if the time series in the OECD (Organization for Economic 
Benedetto Lepori obtained his degree in mathematical physics at the University of Rome in 1988 and a PhD in communication sciences at the University of Lugano in 2004. Since 1988, he has worked as political consultant and in the management and administration of research in Switzerland. He was national expert at the European Commission for the Forecasting and Assessment in Science and Technology program in 1994 and has worked for the Swiss Science Council. Since 1997, he has been responsible of the research office of the Università della Svizzera Italiana. His research interests cover Swiss higher-education and research policy, the production of S\&T indicators, especially concerning research funding and expenditure, and the introduction of new communication technologies in higher education.

Cooperation and Development) MSTI (Main Science and Technology Indicators) databases start in 1981, in practice, it is impossible to analyze periods longer than ten years because of breaks in the series (Godin, 2005).

Moreover, the limitations of these data are wellknown (see Irvine et al, 1991; Godin, 2005). ${ }^{1}$ These include: differences among countries in the methodology for data collection and in the implementation of definitions from the Frascati Manual (OECD, 2002); problems in the measure of the share of research in higher-education expenditure; and the lack of analytical categories needed for policy analysis, including project funding, and of detail in the data concerning funding agencies, instruments and scientific disciplines.

The main aim of this paper is to show that, through a combination of different data sources, it is possible, at least at national level, to reconstruct a picture of the changes in public funding of research during the last 30 years (with some information on the period from the end of World War II). More specifically, I will concentrate on three issues:

- the evolution of the level of public funding;

- the changes in the share between institutional and project funding, and in the resources devoted to universities vs public research laboratories;

- the changes in the portfolio of project funding instruments.

I will frame these changes in the historical development of the Swiss research policy (see Benninghoff and Leresche, 2003; Lepori, 2004) and interpret them in relation to the interaction between international developments in the field, specific features of the Swiss case and the strategies of the involved actors. This will also allow us to identify major turning points in research policy and public research funding.

In the next section, I introduce some basic definitions and categories for the analysis. I then review the international literature on the subject and identify some research questions for the Swiss case. The following section contains the quantitative analysis, including information on sources and methodology.
The final section frames these results in the development of Swiss research policy since the World War II.

\section{Definitions and main categories}

I define public research funding as funds provided by the State for research activities. This definition is based on the intention of the funding agency rather than on the activity performed, as in the R\&D statistics. However, where funds are attributed jointly for different activities, as for higher education, I shall use performer's data to identify the research share.

Since Switzerland is a federal country, the State comprises central authorities (in Switzerland the Confederation) and regional authorities (the cantons). For this research, I leave out local authorities, since their contribution is less important. The State includes international organizations such as the European Union (EU), and international programs.

Following Millar and Senker (2000), it is useful to distinguish the following categories of instruments.

1. General funds to higher-education institutions. In most cases, these funds are attributed jointly for education and research as a global budget, whose repartition is left to internal decision-making processes. However, the total amount might be calculated on the basis of input (for example, number of students or amount of project-funding grants) or on the level and quality of output (for example, degrees and scientific publications). Recent trends include the use of formulae instead of historical keys, and some use of output measures and the contractualization of the relationships between the state and higher-education institutions (see Kaiser et al, 2001).

2. General funding of public laboratories outside the universities. Many laboratories are missionoriented, but some are also devoted to academic research (Max-Planck Gesellschaft in Germany; international research organizations such as CERN). General funds are normally attributed as block grants, but contractualization has been a widespread trend.

3) Project funding. I define project funding as funds attributed directly to a team for a research activity limited in duration and scope. It comprises a variety of instruments that can be classified according to the organization attributing the funds - ministries, intermediary organizations, international research organizations - and the type of program or the intention of the funding agency. A very rough division is between programs that promote academic science and those targeted to political or economic goals.

Combined with the division of the research system in higher-education organizations, public research organizations outside higher education and the 
private sector, ${ }^{2}$ these categories allow some simple indicators for public funding to be defined:

- The ratio between general and project funding;

- The ratio between funding for higher education and public research laboratories;

- The share of project funding in higher-education funding.

\section{Public research funding: main issues}

Among the issues concerning public research funding, three deserve our attention:

- The evolution of the level of public funding and the hypothesis of a stagnation of funding levels starting during the 1970s ("steady state" (Ziman, 1994))

- The changes in the portfolio of funding instruments, namely their diversification and the shift to instruments where the state seeks greater control over the research performed.

- The shift in the share of funds among performers, notably between higher-education institutions and public research laboratories.

\section{From growth to steady state}

The literature on research policy identifies a major change between the years following World War II, where public funding increased strongly, and the period from 1970 characterized by a stagnation of available resources (Ziman, 1994). Some factors have been identified as possible explanations:

- The deterioration of the economic climate and of the state of public finances in the OECD countries after the oil shock of 1973;

- A change in public policies from the beginning of the 1980s with the neo-liberal governments, especially in the USA and the UK, promoting a reduction of state intervention and the need for an efficient use of public resources;

- Some disillusionment concerning the capacity of

\section{Three issues concerning public} research funding, deserve our attention: the evolution of the level of public funding and the hypothesis of a stagnation starting in the 1970s; the changes in the portfolio of funding instruments; the shift in the share of funds among performers science to solve social and economic problems and the criticism of academic science, perceived as too far removed from the needs of society (Elzinga and Jamison, 1995).

There is some empirical evidence for this change; for instance, in the USA, Federal Government funding increased threefold, in real terms, between 1953 and 1963, whereas, in the period 1963-2002, the increase was only $25 \%$ (National Science Foundation, 2003). For European countries, data from the OECD MSTI database for the period 1981-2000 show that, in real terms, public funding of R\&D has slightly increased in most countries, with the main exception being the UK, and with large differences among countries. Overall, it seems that, if measured as a percentage of GDP (gross domestic product), public funding to research has not increased significantly in the last few years (OECD, 2003a).

However, these data can give at best a rough idea of the development. Moreover, except for the USA, data do not allow a return to the crucial period at the beginning of the 1970s to compare it with the $1950 \mathrm{~s}$ and 1960s. Thus, a first objective of this study is to reconstruct for the Swiss case covering most of the period after World War II.

\section{Shifts in the instruments portfolio}

A parallel trend has been a shift in the composition of funding instruments (OECD, 1998; Geuna, 2001; OECD, 2003a):

- Concerning the general funding of universities and laboratories, a shift from funding based on historical criteria to the use of performance criteria, the introduction of evaluation tools, and of contracts (Geuna and Martin, 2003; Kaiser et al, 2001).

- Concerning project funding, a shift towards instruments aiming to solve political problems or to promote technological development, respectively, and thus to instruments where the state has a greater influence on the choice of research themes and in the selection of the beneficiaries to promote technological development (Braun et al, 2003; Geuna 2001); hence, there has been pressure from the state on research councils to orient their funds towards political priorities (Godin et al, 1999; Benner and Sandström, 2000; Braun et al, 2003).

- An increase in the share of project funding and a reduction of general funds, notably for universities (Geuna, 2001; OECD, 2003a).

These changes have been seen as a consequence of the will of the state to steer research organizations more actively and to apply incentives for greater efficiency. In more abstract terms, they have been interpreted as a consequence of changes in the delegation model from the state to the scientific community (Braun, 2003): while in the 1950s and 1960s, 
'blind' delegation prevailed, later the state adopted models giving more control over the research performed.

Some of these trends are well assessed; for instance, the introduction of policy-oriented research programs in the 1970s and of strategic programs in technological domains in the 1980s is documented in different countries (Braun et al, 2003; Larédo and Mustar, 2001). Similar documentation exists for the use of contracts for general funding of public research organizations (Braun, 2003). However, quantitative evidence is anecdotal: for example, there are almost no data on the share of project funding in different countries, since this category is not existent in $\mathrm{R} \& \mathrm{D}$ statistics; ${ }^{3}$ also, there are no quantitative studies on shifts in the portfolio of instruments.

Moreover, some studies suggest that public funding has evolved through the addition of new instruments that parallel the existing ones, rather than through their replacement; at least in some countries, the pattern would then be one of incremental change rather than of discontinuity (Benner and Sandström, 2000). Thus, the second major task of this paper will be to assess these changes quantitatively over a sufficiently long span of time

\section{Organization of public research systems}

A third issue concerns differences among countries in the structure of public-sector research (PSR) and changes over time in the balance among performer categories, particularly between public research laboratories and universities. Both qualitative evidence from comparative studies and quantitative data show large differences among countries in the organization of public research systems (Senker et al, 1999; OECD, 2003a). There is also some evidence of changes in their organization (Senker et al, 1999; Potì and Reale, 2000); whereas some authors suggested that universities were losing ground (Gibbons et al, 1994), there is now a consensus that they are becoming more central even in countries, such as France, where their role was limited in the past (Mustar and Larédo, 2001).

In such a context, Switzerland is an interesting case. According to OECD data, it is one of the countries that, together with Sweden and Belgium, has the highest share of higher education in publicsector research. Thus, the third empirical question will be to measure over time the share of highereducation institutions in public funding and to understand when and how their dominance in the Swiss public research system has been established.

\section{Results and analysis}

In this section, I present the main quantitative results. The analysis is preceded by a short presentation of the main funding instruments and by a section on data availability and treatment.

\section{An overview of the funding instruments}

Table 1 shows the main public funding instruments for research in Switzerland.

General funding of higher-education institutions The Swiss higher-education system is composed of ten cantonal universities, under the sovereignty of their canton, by the two Federal Institutes of Technology (FIT) in Lausanne and in Zurich, governed by the Confederation, and by seven Universities of Applied Sciences (UAS) (OECD, 2003b). The latter, which were created in the 1990s through a reform of the cantonal higher technical schools, offer professionally oriented curricula and are charged with developing applied research and technology transfer to the regional economy.

The share of power between the central state and the cantons generates a complex funding structure for higher education (Perellon and Leresche, 1999; Perellon, 2001). The two FIT are financed by the Confederation through the FIT board, while cantonal universities are financed by their home canton, but also receive subsidies from the Confederation and from the other cantons. The subsidies from the Confederation are divided among the universities according to the number of students and research grants received by the university (before 2000 the

Table 1. Main funding instruments

\begin{tabular}{|c|c|c|}
\hline Category & Instrument & Start date \\
\hline \multirow[t]{4}{*}{$\begin{array}{l}\text { General funds } \\
\text { to higher } \\
\text { education }\end{array}$} & $\begin{array}{l}\text { Funds from the Confederation to } \\
\text { the Federal Institutes of } \\
\text { Technology }\end{array}$ & 1854 \\
\hline & $\begin{array}{l}\text { Funds from the Confederation to } \\
\text { the cantonal universities } \\
\text { (University Act) }\end{array}$ & 1967 \\
\hline & $\begin{array}{l}\text { Funds of the university cantons } \\
\text { to their university }\end{array}$ & Before 1848 \\
\hline & $\begin{array}{l}\text { Funds of cantons to other cantonal } \\
\text { universities (inter-cantonal } \\
\text { agreement) }\end{array}$ & 1981 \\
\hline \multirow{3}{*}{$\begin{array}{l}\text { General funds } \\
\text { to public } \\
\text { research } \\
\text { laboratories }\end{array}$} & $\begin{array}{l}\text { Funds to the institutes of the FIT } \\
\text { domain }\end{array}$ & $\begin{array}{l}\text { End of 19th } \\
\text { century }\end{array}$ \\
\hline & $\begin{array}{l}\text { Funds to institutes outside the } \\
\text { higher education sector } \\
\text { (Research Act) }\end{array}$ & 1983 \\
\hline & $\begin{array}{l}\text { Contributions to international } \\
\text { organizations (CERN, ESA, ESO, } \\
\text { etc) }\end{array}$ & 1960s \\
\hline \multirow[t]{9}{*}{ Project funding } & SNF free research projects & 1952 \\
\hline & SNF national research programs & 1975 \\
\hline & SNF priority programs & 1991 \\
\hline & $\begin{array}{l}\text { SNF National Centers of } \\
\text { Competence in Research }\end{array}$ & 2000 \\
\hline & SNF individual grants & 1952 \\
\hline & $\begin{array}{l}\text { Commission for Technology and } \\
\text { Innovation projects }\end{array}$ & 1944 \\
\hline & $\begin{array}{l}\text { Contracts from the federal and } \\
\text { cantonal administration }\end{array}$ & NA \\
\hline & European research programs & 1987 \\
\hline & $\begin{array}{l}\text { Other international programs } \\
\text { (Eureka, COST, International } \\
\text { manufacturing systems }\end{array}$ & 1980s \\
\hline
\end{tabular}


allocation was based on actual costs). The contribution from other cantons is calculated according to the number of students from those cantons studying in the university. Similar rules apply to Universities of Applied Sciences.

General funding of public laboratories In Switzerland, this sector comprises: four research institutes included in the FIT domain (the largest being the Paul Scherrer Institute, covering physics, materials science and environmental sciences ${ }^{4}$ ); some institutes and research activities in the federal administration (the largest being six institutes conducting research on agriculture); and some establishments in the cantonal administrations, notably in the cantonal hospitals. There is also a small group of independent public research institutes, the most important being two national research institutes on cancer and the Swiss Center for Research in Microelectronics. Some international organizations like the CERN, the European Space Agency (ESA) and the European Space Observatory (ESO) are also included, since they perform similar tasks to national research laboratories (Irvine et al, 1991).

With the exception of a small amount of funding for non-university institutes, based on the Research Act, there is no specific instrument for funding these organizations. FIT institutes have a specific line in the budget of the FIT domain, while research activities in cantonal and federal administration are funded by their ordinary budgets. Funding for international research organizations is based on international agreements.

Project funding There are two main agencies for project funding in Switzerland: the Swiss National Science Foundation (SNF) for academic research; and the Commission for Technology and Innovation (CTI) for applied research. The SNF is a private foundation, almost entirely funded by the state. It is managed by university professors. Its main instrument is the so-called "free" research projects that fund university research to produce new scientific knowledge and to support PhD students. Starting in the 1970s, the SNF also manages a series of programs (national research programs, priority programs, national competence centers in research), where the Federal Government participates in the decision on research subjects or on the selection of projects. The CTI provides subsidies for joint projects between universities and industry. It is composed of representatives from the private economy, academia and the public administration.

Since the end of the 1980s, Switzerland has participated in the European Framework Programs on a project-by-project basis and with national funding. Since 1992, she has accepted the decisions of the EU concerning selection of projects and funding for Swiss participants (Balthasar et al, 2001). Finally, both the federal and cantonal administrations award research contracts in some policy domains (energy, health, environment).

\section{Methodology and sources}

Official R\&D statistics can hardly be used to answer the questions discussed here (Irvine et al, 1991; Lepori, 2005c). Besides technical difficulties (break in series; changes in the definitions and delimitations used; difficulties with the calculation of general university funds), these statistics have been designed essentially to measure the national effort in $R \& D$ and to allow policy-makers to evaluate whether their country is keeping pace with others (especially the USA). Issues concerning the repartition between channels or allocation mechanisms were scarcely addressed, so R\&D statistics lack the necessary analytical categories (such as the concept of intermediaries or the distinction between general and project funding).

Thus, I will resort to a combination of different data sources summarized in Table 2 (for an overview of

Table 2. Main data sources

\begin{tabular}{|c|c|c|c|}
\hline Instrument & Provider & Period & Remarks \\
\hline State budget & $\begin{array}{l}\text { Swiss Federal Statistical Office } \\
\text { Federal Administration of Finances }\end{array}$ & 1950-2000 & Outlays (effective payments) \\
\hline Higher-education finances & Federal Administration of Finances & 1970-1992 & $\begin{array}{l}\text { No distinction between research } \\
\text { and education }\end{array}$ \\
\hline Higher-education finances & Swiss Federal Statistical Office & 1994-2002 & $\begin{array}{l}\text { Including detailed data on R\&D } \\
\text { expenditure }\end{array}$ \\
\hline Public funding to international organizations & Swiss Federal Statistical Office & 1969-2002 & Survey on $R \& D$ \\
\hline R\&D expenditure of FIT institutes & Swiss Federal Statistical Office & 1969-2002 & Survey on $R \& D$ \\
\hline Contracts from the federal administration & Swiss Federal Statistical Office & 1969-2002 & Survey on R\&D \\
\hline Project funding & Swiss Science Council & 1988-1999 & $\begin{array}{l}\text { Detailed data for the most } \\
\text { important instruments }\end{array}$ \\
\hline Project funding & $\begin{array}{l}\text { Data from funding agencies } \\
\text { Data on international programs from the } \\
\text { Federal Office of Education and Science }\end{array}$ & $\begin{array}{l}1970-1987 \\
2000-2003\end{array}$ & Annual reports \\
\hline
\end{tabular}


A combination of different data sources was used, so first it was necessary to gather these data, which had then to be corrected for breaks in series and changes in definitions and, in some cases, missing years had to be interpolated: then they were combined to produce the required indicators

S\&T indicators in Switzerland see Lepori (2005a)). First it was necessary to gather these data, which had then to be corrected for breaks in series and changes in definitions; in some cases, missing years had to be interpolated. Finally, I combined them to produce the required indicators (for complete methodological information see Lepori (2004)). ${ }^{5}$

\section{Overall level of public funding}

State budgets are the only figures that allow public research funding since World War II to be examined. Figures for actual outlay (money paid during the year) are available for this period (Siegenthaler, 1996; SFSO, 2004; Federal Administration of Finances, 2004). These data include two categories:

- Higher education. This includes general funds for the two Federal Institutes of Technologies and for cantonal universities (from the end of the 1990s, it also covers the Universities of Applied Sciences).

- Research (central state only). This includes project funding, research expenditure of the ministries, general funding to laboratories and contributions to international organizations. There are no data on the direct outlay for research from regional authorities.
We notice that the total outlay over the period 1950 2000 in real terms increased by 15 times. However, whereas in the period 1950-1975, research and higher education funds increased, as did their share in total public outlay and GDP, after 1975, funding followed the rate of economic growth and expansion of state budgets. Also, in the period 1950-1975, the resources per student tripled, whereas they have diminished since 1980 . Thus, the theory that there was a change at the beginning of the 1970s is confirmed, but it would be an exaggeration to speak of stagnation afterwards.

A more detailed analysis reveals a shift in the role of the Confederation and the cantons. In the years 1950-1965 we notice a specialization, with the Cantons bearing most of the funding for higher education, while the Confederation increased direct funding to research. In the period 1965-1975, federal funding for higher education exploded and, since then, there has been no fundamental shift in the share of the three channels considered.

\section{Composition of public funding}

Since the beginning of the 1970s, more detailed data have been available, including the R\&D surveys of the Swiss Federal Office of Statistics and highereducation financial data. By combining these sources, it is possible to produce some more detailed indicators.

Higher-education general funding Higher-education financial statistics were produced until 1991 by the federal administration of finances and, from 1994, by the Swiss Federal Statistical Office. For the general budget of the university, it has been possible to correct older data to make them comparable (Lepori, 2004). ${ }^{6}$ The greatest difficulty is, however, the evaluation of the R\&D share, since, before 1992, only estimates are available.

Thus, after 1992, I used the official data from Swiss Federal Statistical Office (SFSO) based on a survey of higher-education personnel. Before 1992,

Table 3. Public outlays for research and higher education

\begin{tabular}{|c|c|c|c|c|c|c|c|c|}
\hline Year & $\begin{array}{c}\text { Confederation } \\
\text { research } \\
\text { (million Sfr at } \\
1980 \text { prices) }\end{array}$ & $\begin{array}{c}\text { Confederation } \\
\text { HE } \\
\text { (million Sfr at } \\
1980 \text { prices) }\end{array}$ & $\begin{array}{l}\text { Cantons HE } \\
\text { (million Sfr at } \\
1980 \text { prices) }\end{array}$ & $\begin{array}{c}\text { Total outlay } \\
\text { (million Sfr at } \\
1980 \text { prices) }\end{array}$ & $\begin{array}{c}\% \text { public } \\
\text { outlay }\end{array}$ & $\%$ GDP & $\begin{array}{l}\text { University } \\
\text { students }\end{array}$ & $\begin{array}{c}\text { Outlay for HE } \\
\text { per university } \\
\text { student } \\
\text { (1000 Sfr at } \\
1980 \text { prices) }\end{array}$ \\
\hline 1950 & 31 & 53 & 114 & 199 & 2.05 & 0.33 & 16,041 & 10 \\
\hline 1955 & 48 & 60 & 134 & 242 & 2.27 & 0.32 & 15,912 & 12 \\
\hline 1960 & 121 & 69 & 220 & 410 & 3.04 & 0.44 & 21,259 & 14 \\
\hline 1965 & 237 & 143 & 340 & 720 & 3.39 & 0.60 & 32,833 & 15 \\
\hline 1970 & 336 & 541 & 642 & 1,519 & 5.36 & 1.02 & 42,092 & 28 \\
\hline 1975 & 430 & 767 & 1,013 & 2,210 & 6.20 & 1.42 & 54,196 & 33 \\
\hline 1980 & 422 & 740 & 1,112 & 2,274 & 5.78 & 1.34 & 61,347 & 30 \\
\hline 1985 & 417 & 731 & 1,169 & 2,317 & 5.56 & 1.27 & 74,806 & 25 \\
\hline 1990 & 549 & 909 & 1,300 & 2,758 & 5.69 & 1.32 & 85,940 & 26 \\
\hline 1995 & 679 & 1,014 & 1,289 & 2,982 & 5.57 & 1.42 & 88,243 & 26 \\
\hline 2000 & 656 & 1,013 & 1,427 & 3,096 & 5.86 & 1.56 & 118,616 & 21 \\
\hline
\end{tabular}


Table 4. Public research funding $\mathbf{1 9 7 0 - 2 0 0 0 ~ ( m i l l i o n ~ S f r ~ a t ~} 1980$ prices)

\begin{tabular}{|c|c|c|c|c|c|c|c|c|c|c|c|c|}
\hline \multirow[t]{2}{*}{ Year } & \multicolumn{3}{|c|}{ Higher education } & \multicolumn{3}{|c|}{ Laboratories } & \multirow{2}{*}{$\begin{array}{c}\text { Other } \\
\text { projects* }\end{array}$} & \multirow[t]{2}{*}{ Total } & \multicolumn{4}{|c|}{ Indicators } \\
\hline & $\begin{array}{l}\text { General } \\
\text { cantons }\end{array}$ & $\begin{array}{c}\text { General } \\
\text { Confederation }\end{array}$ & Project & $\begin{array}{c}\text { FIT } \\
\text { institutes }\end{array}$ & $\begin{array}{l}\text { Federal } \\
\text { admin- } \\
\text { istration }\end{array}$ & $\begin{array}{l}\text { International } \\
\text { organiza- } \\
\text { tions }\end{array}$ & & & 1 & 2 & 3 & 4 \\
\hline 1970 & 120 & 110 & 123 & 110 & 93 & 29 & 85 & 670 & 53 & 31 & 59 & 31 \\
\hline 1975 & 170 & 199 & 122 & 92 & 147 & 56 & 62 & 848 & 58 & 23 & 66 & 22 \\
\hline 1980 & 362 & 331 & 221 & 211 & 187 & 115 & 125 & 1552 & 59 & 22 & 64 & 22 \\
\hline 1985 & 263 & 222 & 133 & 122 & 122 & 77 & 92 & 1032 & 60 & 20 & 59 & 22 \\
\hline 1990 & 305 & 276 & 172 & 167 & 158 & 134 & 111 & 1324 & 57 & 21 & 61 & 21 \\
\hline 1995 & 441 & 373 & 234 & 174 & 131 & 119 & 121 & 1593 & 66 & 22 & 66 & 22 \\
\hline 2000 & 326 & 297 & 218 & 177 & 60 & 111 & 75 & 1264 & 67 & 24 & 74 & 23 \\
\hline
\end{tabular}

Notes: $\quad$ * project outside higher education (private, laboratories, PNP and higher technical schools).

Indicators are: 1 = higher education as \% of total public funding of research;

2 = project funding as \% of higher-education funding; calculation also includes other funds in the general budget not included in the table

3 = higher education as $\%$ of project funding

4 = project funding as $\%$ of total public funding

I adopted a flat rate of 0.4 . Since older estimates are under 0.4 , this choice could eventually over-estimate research expenditure in higher education. ${ }^{7}$ For the sake of comparability, I do not include the UAS since they were only created in 1995.

General funding for public research laboratories The SFSO produced time series for the R\&D expenditure of FIT institutes and the federal administration, and the R\&D contributions to international organizations. These data are collected through a survey and distinguish between $R \& D$ activities and other activities. For other institutes, an estimate is possible only for the years 1996-2000, giving 60m Swiss francs (Sfr) for the federal contribution (Conseil Fédéral, 1998). For lack of older data, I do not include previous years in the time series. ${ }^{8}$

Project funding was calculated as explained in the next section.

Table 4 summarizes the results, while Figure 1 compares the share of funding between the main groups of performers in 1970 and 2000. These data are different from the preceding ones, since we consider here only

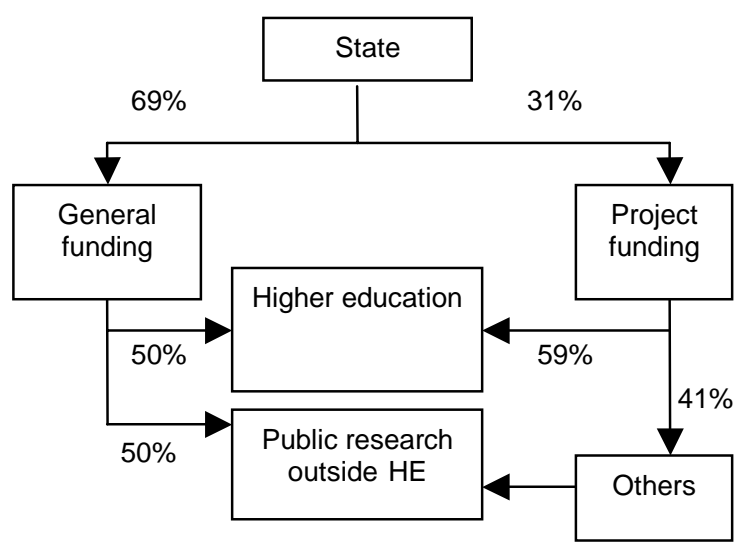

the research expenditure in higher education and research institutes, excluding educational and service activities. The total amount of public funding calculated here for the year 2000 (2568m Sfr) compares well both with official R\&D figures $(2475 \mathrm{~m} \mathrm{Sfr})$ and with Government Budget Applications or Outlays on R\&D (GBAORD) (2700m Sfr). This shows that the aggregate figures do not depend too much on the chosen methodology.

These data confirm that public funding of research has increased, but with a marked stagnation for 1975-1980 and even a decrease in real terms for 1995-2000 (followed, however, by an increase in 2000-2004). Secondly, the share of universities has grown in the period considered here. Since budgetary data (see Table 3 ) also show a large expansion of higher-education funding at the end of the 1960s, we can conclude that the transition to a system dominated by the universities did occur essentially in the period 1965-1975. Finally, over the whole period, there is no increase in the share of project funding, but a decrease in the 1970s; this has been partially compensated for in the years 1985-1995. Universities also receive a very large (and increasing) share of project funding.

Figure 1. Share of public research funding 1970 and 2000

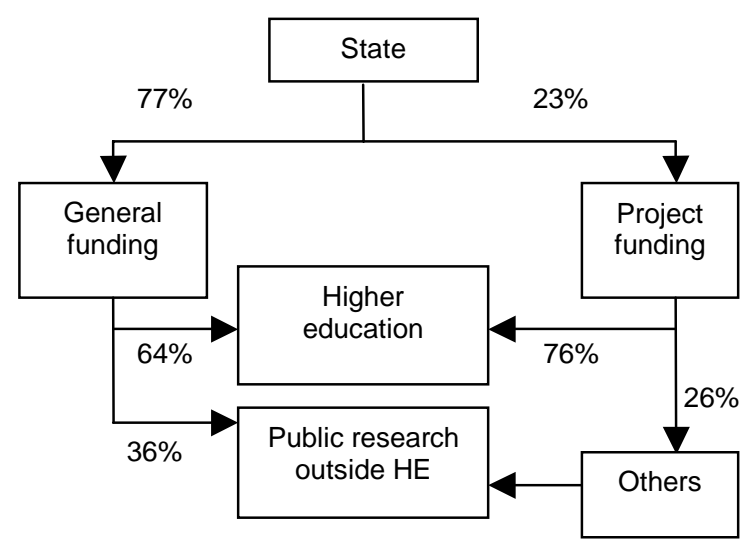




\section{Evolution of project funding}

To analyze project funding, I will follow an approach based on the definition of a set of instruments according to the intention of the funding agency:

- Swiss National Science Foundation instruments, including individual grants.

- CTI instruments, including Eureka.

- European Framework programs, COST (scientific and technical cooperation) and contracts of the ESA.

- Research contracts of the federal and cantonal administration.

In the Swiss case, there are relatively few delimitation problems, since there are practically no funds going to private companies (where it could be difficult to distinguish between research and economic support) and there is a clear distinction between general funding and project funding. The major exception is the European Space Agency contracts, where it is hard to distinguish between research and production contracts, for lack of detailed data but also because the distinction is difficult to apply to the space sector. Hence, I include all ESA contracts.

Moreover, fairly complete data are available both from a database built by the Swiss Science Council (SSC) for the years 1988-1999 and from the annual reports of the funding agencies (see Table 2). Data on $\mathrm{R} \& \mathrm{D}$ contracts from the federal administration have been collected since 1969 by the SFSO through a survey. Finally, detailed data for the European programs are available, given that until 2002 Swiss participants were funded directly from the Confederation.

The only data missing are for ESA contracts, where only an estimate for the year 2002 has been possible, and for research contracts of the cantonal administrations, where there are no data except for contracts to higher education in the most recent years. I will include these two instruments in the analysis for 2002 only, but not in the time series (see Lepori (2005b) for full details).

Figure 2 shows, for 2002, the share of project funding between instruments and beneficiaries, while Table 5 shows the evolution between 1970 and 2000. These data show that project funding stagnated between 1970 and 1985 and increased rather strongly in the subsequent years. The increase is largely a result of the diversification of instruments. In 1970, few instruments existed (SNF projects and grants, CTI projects, public contracts especially in the defense sector), while others were added in the period 1970-2000: the National Research Programs in 1975; priority programs at the end of the 1980s; the National Centers of Competences in Research in 2000; and the international research programs in the 1980s and 1990s (especially the European Framework Programs).

Secondly, we notice changes in the composition of instruments. In 1970, project funding was divided between two agencies: the SNF funding academic research; and the Defense Ministry awarding contracts to private companies for the development of defense systems. In 2002, the SNF share diminished, but was still quite important; the SNF also manages an instrument for policy-oriented research (the national research programs), a technology-oriented instrument (the priority programs), and a network of excellence program (NCCR). The role of the federal administration has clearly diminished, but this is essentially the result of a large decrease in military contracts to private companies. Finally, we notice the emergence of the international component that, in 2002 , covered about $30 \%$ of project funds (including ESA contracts).

Project funding is also dominated by highereducation institutions. The limited share of private
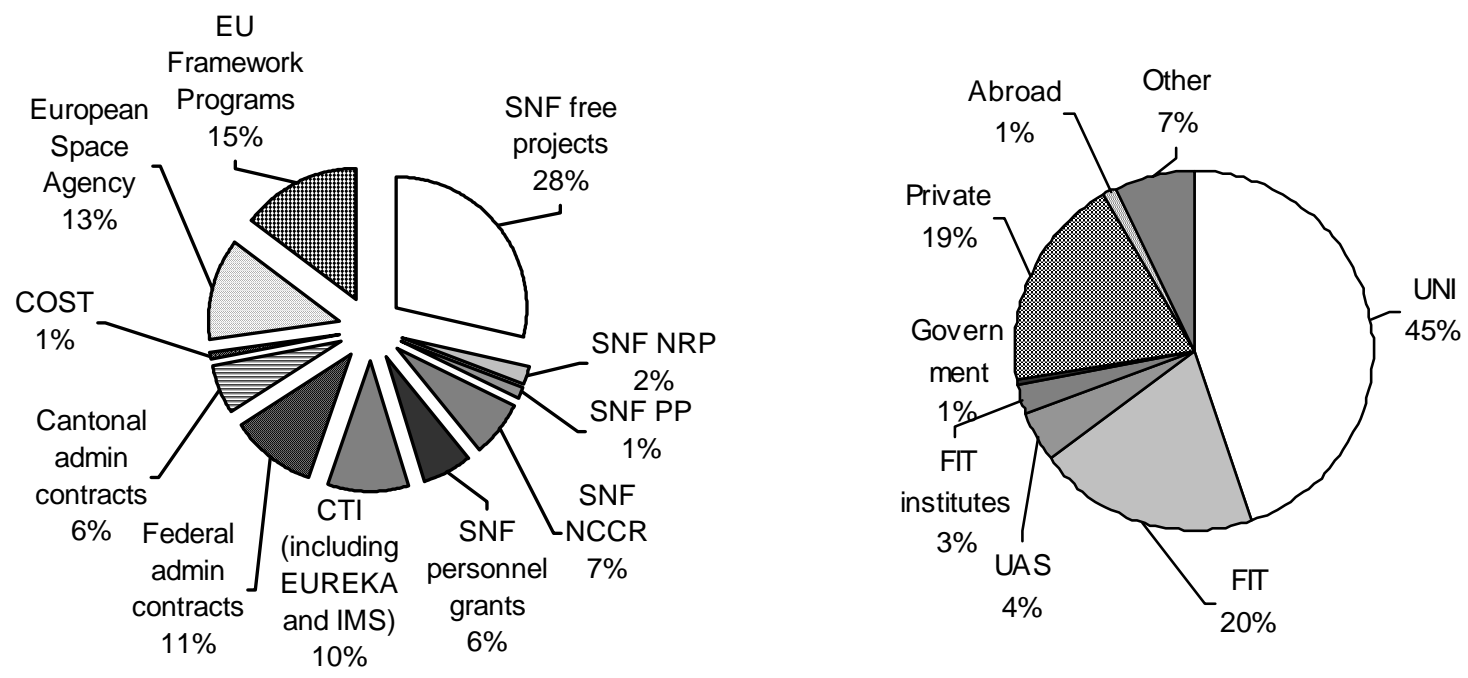

Figure 2. Project funding in 2002: share by instruments and by beneficiary group

Note: The category other includes non divided data for SNF for public research laboratories, PNP (including individuals) and some funds to private companies 


\begin{tabular}{|c|c|c|c|c|c|c|c|c|}
\hline \multirow[t]{2}{*}{ Year } & \multicolumn{2}{|c|}{ SNF } & \multirow[t]{2}{*}{ CTI } & \multirow[t]{2}{*}{ Contracts } & \multirow[t]{2}{*}{ International } & \multirow[t]{2}{*}{ Total } & \multirow[t]{2}{*}{$\%$ expend-iture* } & \multirow[t]{2}{*}{$\%$ GDP } \\
\hline & Academic & Programs & & & & & & \\
\hline 1970 & 124 & 0 & 4 & 80 & 0 & 208 & 0.73 & 0.14 \\
\hline 1975 & 120 & 3 & 4 & 57 & 0 & 184 & 0.51 & 0.12 \\
\hline 1980 & 124 & 13 & 11 & 64 & 0 & 211 & 0.54 & 0.12 \\
\hline 1985 & 116 & 14 & 12 & 84 & 0 & 226 & 0.54 & 0.12 \\
\hline 1990 & 131 & 16 & 20 & 111 & 4 & 283 & 0.58 & 0.14 \\
\hline 1995 & 147 & 49 & 23 & 103 & 33 & 356 & 0.66 & 0.17 \\
\hline 2000 & 142 & 28 & 36 & 42 & 45 & 294 & 0.56 & 0.15 \\
\hline Note: & $\begin{array}{l}\text { * \% of total expe } \\
\text { SNF academic: } \\
\text { SNF programs: } \\
\text { CTI also include } \\
\text { International: EL }\end{array}$ & $\begin{array}{l}\text { e of the Cor } \\
\text { search proj } \\
\text { al research } \\
\text { ka } \\
\text { lework Prog }\end{array}$ & $\begin{array}{l}\text { ation } \\
\text { yrants } \\
\text { ams a } \\
\text { and } \mathrm{C}\end{array}$ & $\begin{array}{l}\text { Iational cen } \\
\text { ority progra }\end{array}$ & competence & earch & & \\
\hline
\end{tabular}

companies is the result of an official policy that companies should not receive public funds (either directly or indirectly) for research. Hence, funds for companies come from international programs $(90 \%$ of ESA contracts benefit private companies) and from contracts of the public administration. The very low share of public research outside higher education - lower than their share in R\&D expenditure - is noteworthy. Overall, higher-education institutions have increased their share of project funding and were the major beneficiaries of the increase in the 1990s.

\section{Public funding and research policy}

Using the results of the previous section, Table 6 divides the period 1945-2000 into four main phases, by considering two criteria: the overall level of public funding; and the priorities of the state concerning the choice of instruments (general funding vs project funding) and the performing sector (higher education vs public research laboratories).

\section{5-1965: specialized roles in a federal state}

The specialized model of the post-war period had its roots in the request for the intervention of the Confederation to support research activities from the mid 1930s (Fleury and Joye, 2002). Since the highereducation sector was essentially managed by the cantons, which refused federal intervention (OECD, 1971), the Confederation concentrated on direct funding of research outside higher education ${ }^{9}$ and on project funding.

Moreover, as a result of the economic crisis of the 1930s and World War II, economic motivations were central: hence, we see the launch of a large program in the atomic energy sector in cooperation with the electromechanical industry (Wildi, 2003) and the creation of an instrument to support research of economic interest in the form of cooperation projects between higher-education institutions and private companies (creation of the CTI in 1944).

Since these measures essentially benefited the Federal Institute of Technology in Zurich, the cantons accepted in 1952 the creation of the Swiss

Table 6. Periodization of public research funding

\begin{tabular}{|c|c|c|}
\hline Period & Level of funding & Orientation \\
\hline 1945-1965 & $\begin{array}{l}\text { Increasing both in absolute terms } \\
\text { and as a share of public } \\
\text { expenditure }\end{array}$ & $\begin{array}{l}\text { Differentiation between cantons and Confederation: the cantons concentrate on the } \\
\text { funding of universities, while the Confederation gives priority to research institutes } \\
\text { (nuclear program) and project funding (SNF) }\end{array}$ \\
\hline 1965-1973 & $\begin{array}{l}\text { Increasing both in absolute terms } \\
\text { and as a share of public } \\
\text { expenditure }\end{array}$ & $\begin{array}{l}\text { Confederation strongly increases funding to the higher-education system, both to canton } \\
\text { universities and to the FIT: project funding still increases, but its share of public } \\
\text { research funding begins to decrease }\end{array}$ \\
\hline 1973-1988 & $\begin{array}{l}\text { Increasing in absolute terms, but } \\
\text { stable or slightly decreasing as } \\
\text { a share of public expenditure }\end{array}$ & $\begin{array}{l}\text { Higher-education funding is prevalent and project funding decreases as a share of total: } \\
\text { there is some specialization, since the Confederation concentrates on funding of the } \\
\text { FIT, the cantons on funding of the cantonal universities }\end{array}$ \\
\hline 1988-2002 & $\begin{array}{l}\text { Increasing in absolute terms, but } \\
\text { stable or slightly decreasing as } \\
\text { a share of public expenditure }\end{array}$ & $\begin{array}{l}\text { Higher-education funding stays the dominant mode of funding, but Confederation gives } \\
\text { some priority to project funding with increases rather strongly in the 1990s because of } \\
\text { which, the creation of new instruments }\end{array}$ \\
\hline
\end{tabular}


National Science Foundation to support basic research in universities (Fleury and Joye, 2002). However, to limit the interference in the autonomy of the universities, the SNF mandate was restricted to funding individual projects assigned on a competitive basis.

Federalism played a central role in this process, leading to a balanced system both on the funding side (with a distinction between central and regional authorities) and on the performers' side (between higher education and public research laboratories). However, the attitude of the private companies against public support for their research and the lack of a public industry prevented strong support of research in public or semi-public companies.

This model evolved in the 1950s and the 1960s: as the result of the economic situation, support for research of economic interest declined, while the nuclear program failed both at the technical level (an accident at the experimental reactor in Lucens in 1967) and at the industrial level (withdrawal of the Swiss industry (Wildi, 2003)). The intervention of the Confederation shifted progressively to support academic research through the SNF, whose role and budget increased strongly.

The SNF expanded its tasks in exchange for additional funding, becoming the dominant organization of Swiss research policy: in 1957, it absorbed the Atomic Energy Commission, in 1965, it received the task of funding research institutes and, in 1969, of funding research in social and preventive medicine. By the beginning of the 1970s, all these tasks had been integrated into the normal funding of academic projects.

\section{5-1973: creating dominance of higher education}

The period 1965-1975 was characterized by a shift in the priorities of the Confederation towards higher education (see Table 3). This has been largely the result of the political pressure of the cantons, which, being faced with a rapid growth of the number of students in their universities, asked for federal support. The decision-making process was very quick: an expert group report was published in 1964 (Département Federal de l'Intérieur, 1964) and already by 1967 , the Confederation began to finance cantonal universities. In 1969, the federal university act entered into force, while, in the same year, the Confederation took over the university engineering school of Lausanne, which became the Ecole Polytechnique Fédérale de Lausanne.

The data document not only the rapidity and importance of the shifts - in real terms, Confederation outlay for higher education increased threefold between 1965 and 1970 - but also that, since 1970, this model has been remarkably stable. Thus, it is in this period that the Swiss public research system adopted the configuration we know today, a conclusion that would hardly have been possible without quantitative data. We notice that the intervention of a powerful political actor - the cantons - was decisive, but also that the situation of public finances allowed money to be put into higher education without conflicting with other priorities.

These changes also had important consequences at the institutional level, since, to coordinate the two FIT, the FIT board was created. This board was actually located midway between the public administration and the two schools: a new powerful actor requiring federal funding for higher education thus entered the scene.

\section{3-1988: economic crisis, internal reorganization}

The data show that the beginning of the 1970s was a watershed in the level of resources available; even if we cannot speak of stagnation, the rate of growth of funding slowed down considerably and became irregular, depending on the economic situation (OECD, 1989). Moreover, in higher education, the available resources did not keep pace with the growth in the number of students.

This change is correlated with economic data, and with the situation of public finances, which worsened dramatically after 1973 (Lepori, 2004). While before 1970 , thanks to the diminution of debts and military spending, the Confederation could assume new tasks, including research and higher education, after 1970 , both the deficits and the increase in social expenditure limited the available resources. In this light, general economic factors seem largely to explain the observed evolution.

However, internal factors were also at work. Documents of this period show dissatisfaction in the political world with the funding practices of the SNF, which was felt incapable of orienting research towards political problems (Hill and Rieser, 1983). We thus find discussions on the creation of a funding agency for policy-oriented research or research of economic interest.

In 1975, the SNF decided to bend to the political pressure, and accepted that it should manage the National Research Programs. With this decision, which was preceded by a hot internal debate, the SNF could keep its budget and avoid competition from a new agency, but at the price of managing programs where the State can choose the research themes. The stagnation of project funding in the 1970s also reflects this conflict situation.

A second element was the crisis in highereducation policy: with the rejection of the constitutional article on higher education in 1973, the Confederation did not gain control over cantonal universities; as a consequence, willingness to increase their funding diminished. Data show that the Confederation concentrated on funding the FIT, while the cantons increased funding to their universities (in 1981 non-university cantons accepted that they should finance cantonal universities). This differentiation favored the FIT, since the Confederation had greater financial means: at the end of the 1990s, 
the FIT domain had $40 \%$ of the whole budget for research, technology and higher education at federal level (Conseil Fédéral, 1998).

\section{8-2000: moderated shift to project funding}

During the 1990s, we notice a shift towards project funding: its share in public funding, which had continuously diminished since 1970, augmented slightly. Again, this change reflects the evolution of the research policy. While higher-education policy was blocked until the new university act of 1999 (Perellon, 2001), the Federal Research Act of 1983 gave responsibility to the Confederation for direct support of research and thus allowed it to launch new research programs without consulting the cantons.

Moreover, in the 1970s and the 1980s, the Swiss Science Council developed the idea of concentrating resources on priority subjects, such as political problems or, later, technological domains (SSC, 1973; 1980). Project funding was then seen by the federal administration as a preferential instrument to implement these priorities in a higher-education system that escaped central coordination.

However, quantitatively the change has been moderated. We could speak of a tendency in favor of project funding, where additional means, if available, were engaged in preference. The financial situation played an important role in this respect, since, in a consensus-based system, shifts in priorities can be implemented essentially using additional financial means.

Moreover, we observe significant changes in the composition of the instruments with the introduction of policy- and technology-oriented instruments and the diminishing role of the intermediary. However, change and differentiation have been fairly moderate: the intermediary agency maintains an important role - even dominant if we consider only national instruments - and the share of academic programs still exceeds $40 \%$.

The most significant factor of change has been the development of the European Framework Programs and Switzerland's decision to participate in them for general political reasons. At a national level, the strategy of the SNF of accepting policy-oriented programs was quite successful in keeping its central role in project funding: when, at the end of the 1990s, political priorities shifted away from thematic programs, the SNF could redirect most of these funds towards more academic instruments (Lepori, 2004; Braun and Benninghoff, 2003).

\section{Conclusions}

The analysis performed here shows that we can identify in the Swiss case some of the general trends in public funding discussed in the literature, but also with significant differences in their magnitude. Thus, the overall picture appears to be much more differentiated than suggested by the literature on the subject.

For instance, Swiss data confirm the slowdown in the growth of public funding at the beginning of the $1970 \mathrm{~s}$, but show that the idea of a 'steady state' is exaggerated. Also, the increase in the share of project funding in the 1980s and 1990s is fairly marginal and, over the period 1970-2002, there is no increase at all. This also shows that drawing conclusions on the long-term evolution from a short time series can lead to misleading interpretations.

Moreover, these data allow a periodization of public research funding in Switzerland that combines general patterns, such as the leveling of resources in the 1970s, with country-specific phenomena, such as the turn towards higher education at the end of the 1960s. In fact, the shift in the federal research policy from technological programs (the nuclear program) and from project funding (SNF) to general funding of higher education in the years 1965-1973 appears to have been the decisive event for the current configuration of the Swiss research system, building a dominance of higher-education institutions that is unmatched in most other European countries.

Thus, this work demonstrates the value of a longterm series on funding for the analysis of research and higher-education policies. With this, I do not intend to imply that the indicators presented here give a complete picture of research funding: more qualitative dimensions, such as policy objectives and rationales, allocation mechanisms and criteria, the relationships between actors, the fine-grained organization of research activities, play a large part in shaping the relationship between state and science, as well as the impact of public funds on research.

However, this analysis shows that quantitative indicators, if developed with precise questions in mind, can be useful as a support for policy analysis and can provide new insights, for example, by identifying turning points in historical developments or following developments over longer time-spans, where it would be difficult to pursue a purely qualitative analysis.

\section{Notes}

1. In this paper, I will refer to data produced according to the definitions and methodology of the Frascati Manual (OECD, 2002) as "R\&D statistics". For a description of the Frascati system, of its origins and limitations see Godin (2005) and Luwel (2004).

2. Ileave out here the private non-profit sector, since its importance is limited in most OECD countries: private non-profit organizations financed more than $50 \%$ by a block grant from the state are included in the State sector (OECD, 2002, chapter 3.6).

3. In the OECD project on steering and funding of public research institutions only four countries provided data on project funding for the period 1996-2000 (OECD, 2003a: 85).

4. Since these four institutes submit to the FIT board, they are included in the official R\&D statistics in the higher-education sector. However, they are both organizationally and functionally separated from the two FIT and thus I consider them as public laboratories. 
5. The author wishes to thank the Swiss Federal Statistical Office for its support in this work, including checking data and delivering some non-published data.

6. Major differences concerned expenditure for investment and on the university hospitals, as well as coverage of third-party funds.

7. The methodological foundation and the quality of data on the share between research and education in universities are questionable. Thus there are good reasons to avoid this repartition and to use the total funding to universities. However, I will use the research share to produce figures that are comparable with official $R \& D$ statistics.

8. International funds are also over-estimated, since a large part of the European Space Agency contribution comes back to Switzerland in the form of contracts (mostly to private companies) and thus should be included in project funds.

9. Most public research institutes were created between the end of the 19th century and World War II: the federal research institutes in agriculture (between 1878 and 1915), three of the four institutes now belonging to the FIT domain (EMPA in 1880, EAWAG in 1945, WSL in 1885), the Swiss meteorological institute (1880).

\section{References}

Balthasar, A, O Bieri, R Kurz and S Kuhlmann 2001. Evaluation der schweizerischen Beteiligung an den FTERahmenprogrammen der Europäischen Union. Bern: Office fédéral de l'éducation et de la science.

Benner, M and U Sandström 2000. Inertia and change in Scandinavian public-sector research systems: the case of biotechnology. Science and Public Policy, 27(6), December, 443-454.

Benninghoff, M and J-P Leresche 2003. La recherché affaire d'Etat. Enjeux et lutes d'une politique fédérale des sciences. Lausanne: Presses Polytechniques Universitaires Romandes.

Braun D 2003. Lasting tensions in research policy-making - a delegation problem. Science and Public Policy, 30(5), September, 309-321.

Braun, D and M Benninghoff 2003. Policy learning in Swiss research policy - the case of national centres of competence in research. Research Policy, 32(10), 1849-1863.

Braun, D, M Benninghoff, R Ramuz and J-P Leresche 2003. Learning Capacities in Public-Funded Research Systems, research report. Lausanne: Université de Lausanne.

Conseil Fédéral 1998. Message relatif à l'encouragement de la formation, de la recherche et de la technologie pendant les années 2000 à 2003. Bern: Conseil Fédéral.

Département Fédéral de l'Intérieur 1964. Rapport de la Commission d'experts sur les problèmes de développement des Hautes Ecole. Bern: Département Fédéral de l'Intérieur.

Elzinga, A and A Jamison 1995. Changing policy agendas in science and technology. In Handbook of Science and Technology Studies, eds. S Jasanoff et al. London: Sage.

Federal Administration of Finances 2004. Dépenses de la Confédération par groupe de tâches 1960-2002. Bern: Federal Administration of Finances.

Fleury, $A$ and $F$ Joye 2002. Les débuts de la politique de recherche en Suisse. Histoire de la création du FNS. Genève: Droz.

Geuna, A 2001. The changing rationale for European university research funding: are there negative unintended consequences?. Journal of Economic Issues, 35(3), 607-632.

Geuna, A and B Martin 2003. University research evaluation and funding: an international comparison. Minerva, 41(4), 277-304.

Gibbons M et al 1994. The New Production of Knowledge. London: Sage.

Godin, B 2005. Measurement and Statistics on Science and Technology. Abingdon: Routledge.

Godin, B, M Trépanier and M Alber 1999. Des organismes sous tensions: les conseils subventionnaires et la politique scientifique. Sociologie et société, 32(1), 3-27.

Guston, D 2000. Between Politics and Science. The Integrity and productivity of Research. Cambridge: Cambridge University Press.

Hill, W and I Rieser 1983. Die Förderungspolitik des Nationalfonds im Kontext der schweizerischen Forschungspolitik. Bern: Haupt.

Irvine, J, B Martin and P Isard 1991. Investing in the Future: An International Comparison of Government Funding of Academic and Related Research. Cheltenam: Edward Elgar.

Kaiser, F, H Vossensteyn and J Koelman 2001. Public Funding of Higher Education. A comparative study of funding mechanisms in ten countries. Enschede: CHEPS.

Larédo, P and P Mustar 2001. Research and Innovation Policies in the New Global Economy. An International Comparative Analysis. Cheltenam: Edward Elgar.

Lepori, B 2004. La Politique de la Recherche en Suisse. Institutions, acteurs et développement historiquei. PhD thesis, Lugano.

Lepori, B 2005a. S\&T data/indicators production. Switzerland. Country report. Paris: European Network of Indicators Producers.

Lepori, B 2005b. Project Funding. Switzerland. Country report. Paris: European Network of Indicators Producers.

Lepori, B 2005c. Methodologies for the analysis of public funding of research. Paper presented at the International Workshop on Methodological Advances in S\&T Indicators Production, Lisbon, 22-23 September.

Luwel, M 2004. The use of input data in the performance analysis of R\&D systems. In Handbook of Quantitative Science and Technology Research, eds. H Moed, W Glänzel and U Schmoch. Dordrecht: Kluwer.

Millar, J and J Senker 2000. International Approaches to Research Policy and Funding: University Research Policy in Different National Contexts. Brighton: SPRU.

Mustar, $\mathrm{P}$ and $\mathrm{P}$ Larédo 2001. Innovation and research policy in France (1980-2000) or the disappearance of the Colbertist state. Research Policy, 31(1), 55-72.

National Science Foundation 2003. National Patterns of Research and Development Resources: 2002 Data Update. Washington DC: NSF.

OECD, Organization for Economic Cooperation and Development 1971. National Science Policies. Switzerland. Paris: OECD.

OECD, Organization for Economic Cooperation and Development 1989. National Science and Technology Policies. Switzerland. Paris: OECD.

OECD, Organization for Economic Cooperation and Development 1998. University Research in Transition. Paris: OECD.

OECD, Organization for Economic Cooperation and Development 2002. Frascati Manual. Proposed Standard Practice for Surveys on Research and Experimental Development. Paris: OECD.

OECD, Organization for Economic Cooperation and Development 2003a. Governance of Public Research. Towards better practices. Paris: OECD.

OECD, Organization for Economic Cooperation and Development (2003b), L'enseignement tertiaire en Suisse. Paris: OECD.

Perellon, J-F 2001. The governance of higher education in a federal country. The case of Switzerland. Tertiary Education and Management, 7(2), 211-224.

Perellon, J-F and J-P Leresche 1999. Co-ordinating the impossible? Current changes of governance patterns in Swiss university policy. In Towards a new Model of Governance for Universities? A Comparative View, eds. D Braun and F-X Merrien. London: Jessica Kingsley.

Potì, B and E Reale 2000. Convergence and differentiation in institutional change among European public research systems: the decreasing role of public research institutes. Science and Public Policy, 27(6), December, 421-433.

Senker, J et al 1999. European Comparison of Public Sector Research Systems. Brighton: SPRU.

SFSO, Swiss Federal Statistical Office 2004 (and previous years). Les Finances Publiques en Suisse 2002. Neuchâtel : SFSO.

Siegenthaler, $\mathrm{H}$ ed. 1996. Historische Statistik der Schweiz. Zürich: Chronos.

SSC, Swiss Science Council 1973. Forschungsbericht. Bern: SSC.

SSC, Swiss Science Council 1980. Forschungspolitische Zielvorstellungen. Bern: SSC

SSC, Swiss Science Council 2000. Projektlandkarte Schweiz 1999. Bern SSC.

Wildi, T 2003. Der Traum von eigenen Reaktor. Die schweizerische Atomtechnologieentwicklung 1945.1969. Zürich: Chronos.

Ziman, J 1994. Prometheus Bound. Cambridge: Cambridge University Press. 